\title{
ПИРОМЕТАМОРФИЗМ КАРБОНАТНЫХ ОСАДКОВ ПРИ ФОРМИРОВАНИИ МАГЕЛАНОВЫХ ПОДВОДНЫХ ГОР
}

\section{Асавин А.М.}

ГЕОХИ РАН, Москва, aalex06@inbox.ru

Большое внимание последнее время обращают на себя современные подводные излияния при формировании подводных гор и океанических островов. К наиболее известным можно отнести извержения Канарского архипелаге о-в Эль Ерро [3, 5], Азорском архипелаге вулкан Пико [4], Западной Пасифики, подводный вулкан вблизи Гуама Марианского трога Рота-1 $[1,2]$ и ряд других. Важно, что эти наблюдения показывают, что даже при относительно завершенной вулканической деятельности в пределах цепи подводных гор или архипелага (Гавайи, Канарский архипелаг) вулканическая активность может продолжаться в некоторых объемах.

Роль таких процессов внутриплитного магматизма подводных гор и океанических островов в истории Земли крайне слабо изучена. В результате работы в рейсе НИС «Геленджик» удалось собрать материалы подтверждающие присутствие подводного вулканизма и при формировании древних меловых Магеллановых подводных гор Тихого океана. Был получен материал по гайотам Вулканолог, Коцебу, Говорова. На верхушке гайотов, при подводной фотосьемке, были обнаружены молодые потоки лавы и (рис. 1 a), для сравнения приведены обрывы сложенные пирокластическим материалом древних отложений (рис. 1б). На (рис. 1 в) видна лавовая труба (лавовод) характерный для подводных излияний элемент, на ее окончании обычно формируется пустотелое вздутие, на фото это вздутие раздроблено. Следует подчеркнуть, что все эти сьемки выполнены на поверхности, гайота где согласно классической теории строения гайота не может быть ничего кроме карбонатных и терригенных отложений.
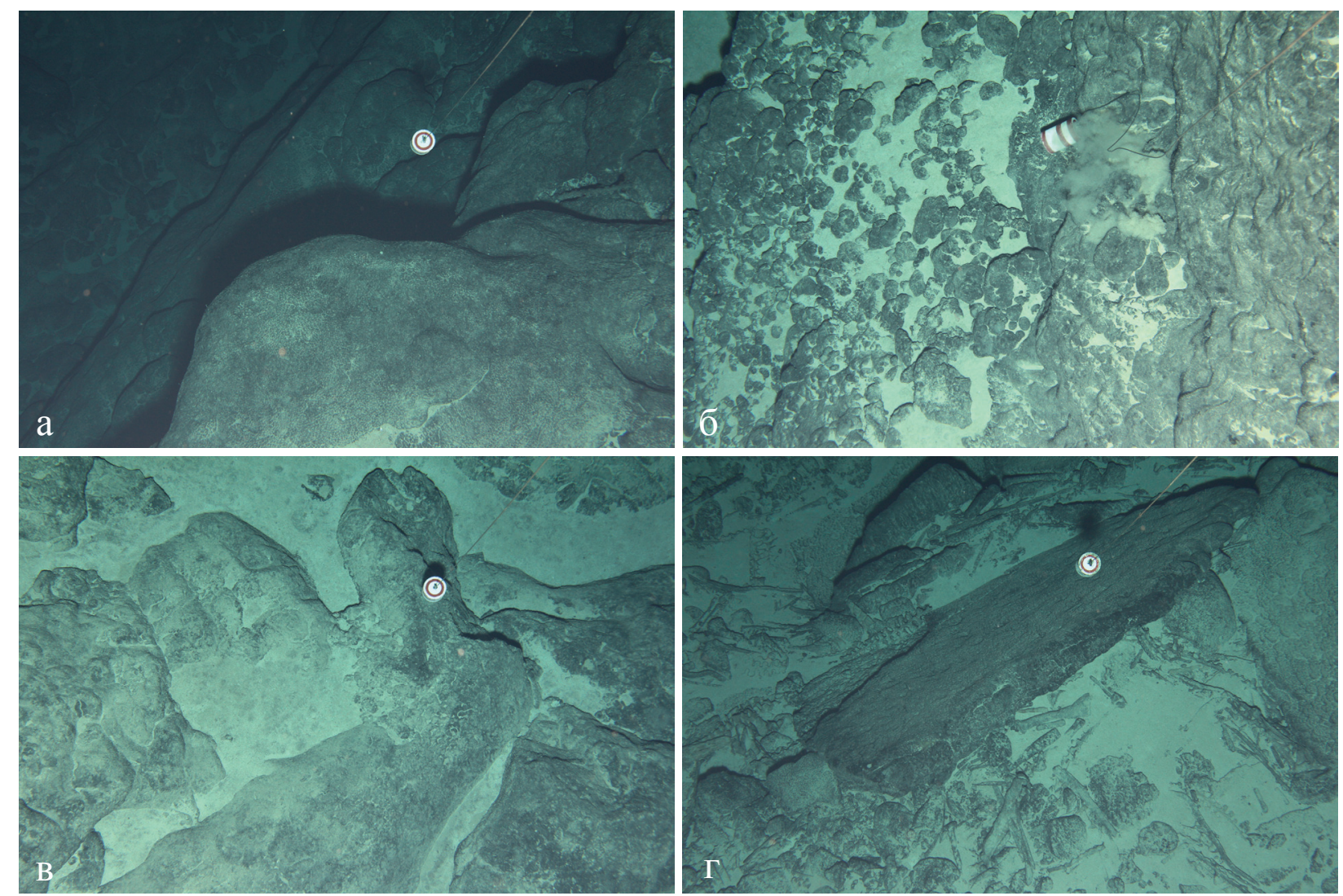

Рис. 1. Подводные фотографии с молодыми излияниями лав на поверхности гайота мелового возраста (белый буйреп на фото имеет диаметр 20см).

a - потоки лав уступ около 10 м высотой, б - уступ сложенный пирокластикой, в - лавовая труба потока с разбитым концом, г - лавовая корка потока. 

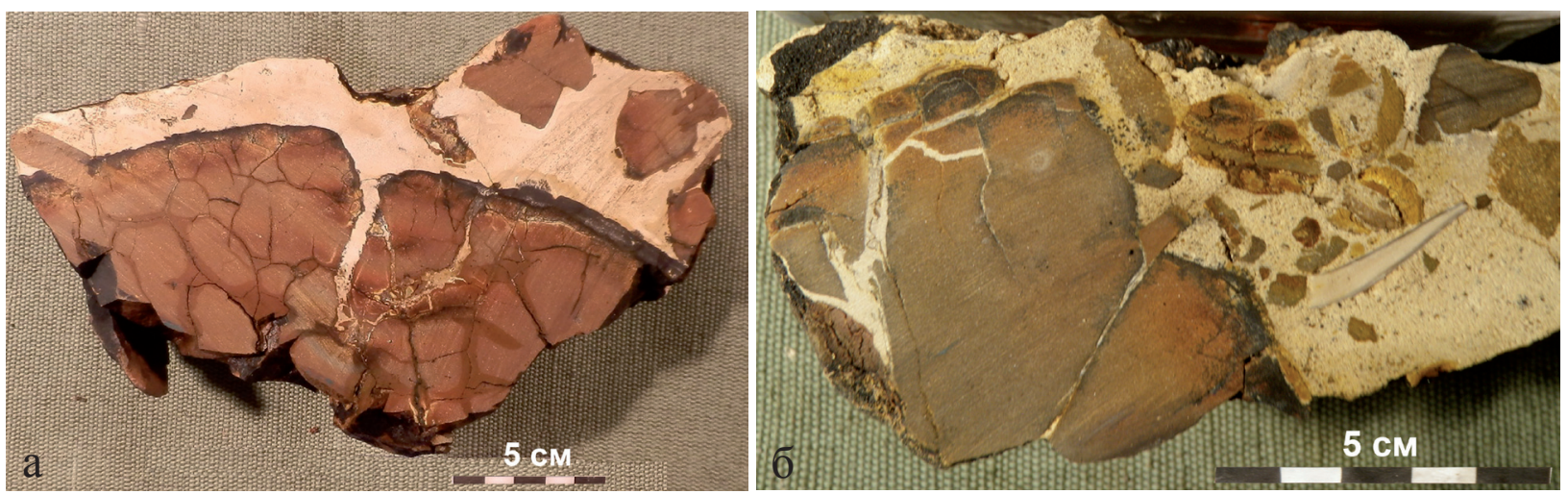

Рис. 2. Фотографии драгированных образцов толеитовых базальтов подводных лав, внедряющихся в рыхлые карбонатные осадки.

a - фото закаленной лавовой корки подводного извержения покрытой карбонатным (белое) осадком, б - фото обломков лавовых корок подводного извержения на карбонатных (белое) осадках с остатками ракушек.

Кроме того детальная батиметрия с помощью многолучевого эхолота выявила большое количество мелких вулканических конусов, лавовых потоков и других вторичных форм рельефа которые могут подтвердить предположения о наличии недавней вулканической активности.

Драгирование на гайоте также позволило обнаружить слабо измененные вулканиты, как лавового типа, так и вулканокластического. И если вулканокластиты могут быть отнесены к этапу наземного формирования гайота, то подводные низко щелочные лавы (рис. 2) могут относиться только к молодым подводным извержениям (рис. 2).

Петрографические исследования драгированных пород показало, что наряду с обычными вулканитами в большом количестве образцов наблюдаются необычные вулканиты в которых проявлены явления ассимиляции карбонатных осадков. Жилки карбонатных осадков подвергаются метаморфизму, превращаясь в кристаллы кальцита, формируя вокруг себя участки измененного стекла и основной массы. Определяются такие минералы как - мелилит, хлорит, цеолиты, галит. Присутствуют характерные для пеперитов структуры автобрекчий, ассимиляционные структуры. Характерно, что незаполненных миндалин нет, они большей частью полностью заполнены различным тонкозернистым карбонатным веществом. Очень характерны размытые по форме напоминающие листья клена очертания включений. Затем они перекристаллизуются в крупнокристаллический кальцит в виде вкрапленников (рис. 3 е). Интересно, что при этом вокруг этих зон перекристаллизации образуются каймы бурого стекла, иногда появляются зоны зеленого хлорита и цеолитов, а в стекле появляются лейсты мелилита. Это свидетельствует о том, что именно в этих зонах, в расплаве существовали области со свободным флюидом, образовавшиеся при пирометаморфизме карбонатных осадков. По-видимому, по состав флюид отвечал системе - CO2-CO-H2O-Cl. Отсутствие в таких гибридизированных породах вкрапленников магнетита, по-видимому, свидетельствует о восстановительном характере флюида. В одной из пород в основной массе обнаружены тонкие структуры закалочных иголок магнетита типа сноповидных кристаллов. То есть окислительная обстановка в расплаве по-видимому не позволяла кристаллизоваться магнетиту (все железо двухвалентное) и только при закалке режим менялся на окислительный. Вообще, для пород характерно наличие тонкозональных минералов вкрапленников - полевого шпата, клинопироксена. Это свидетельствует о сложной истории излияния лав, наличия промежуточных камер.

Были драгированы вулканиты насыщенные крупными (до 3-см) кристаллами полевого шпата. Это можно интерпретировать, как длительное существование магматических стационарных очагов с расплавом, где в условиях постоянства температуры долго поддерживалось кристалл-расплавное равновесие.

Это закономерно приведет к следующим следствиям при пирометаморфизме пород гайотов расплавы пониженной щелочности в процессах ассимиляции карбонатной крышки гайота и рыхлых осадков должны превращаться в своеобразные высоко кальциевые и щелочные расплавы, при- 

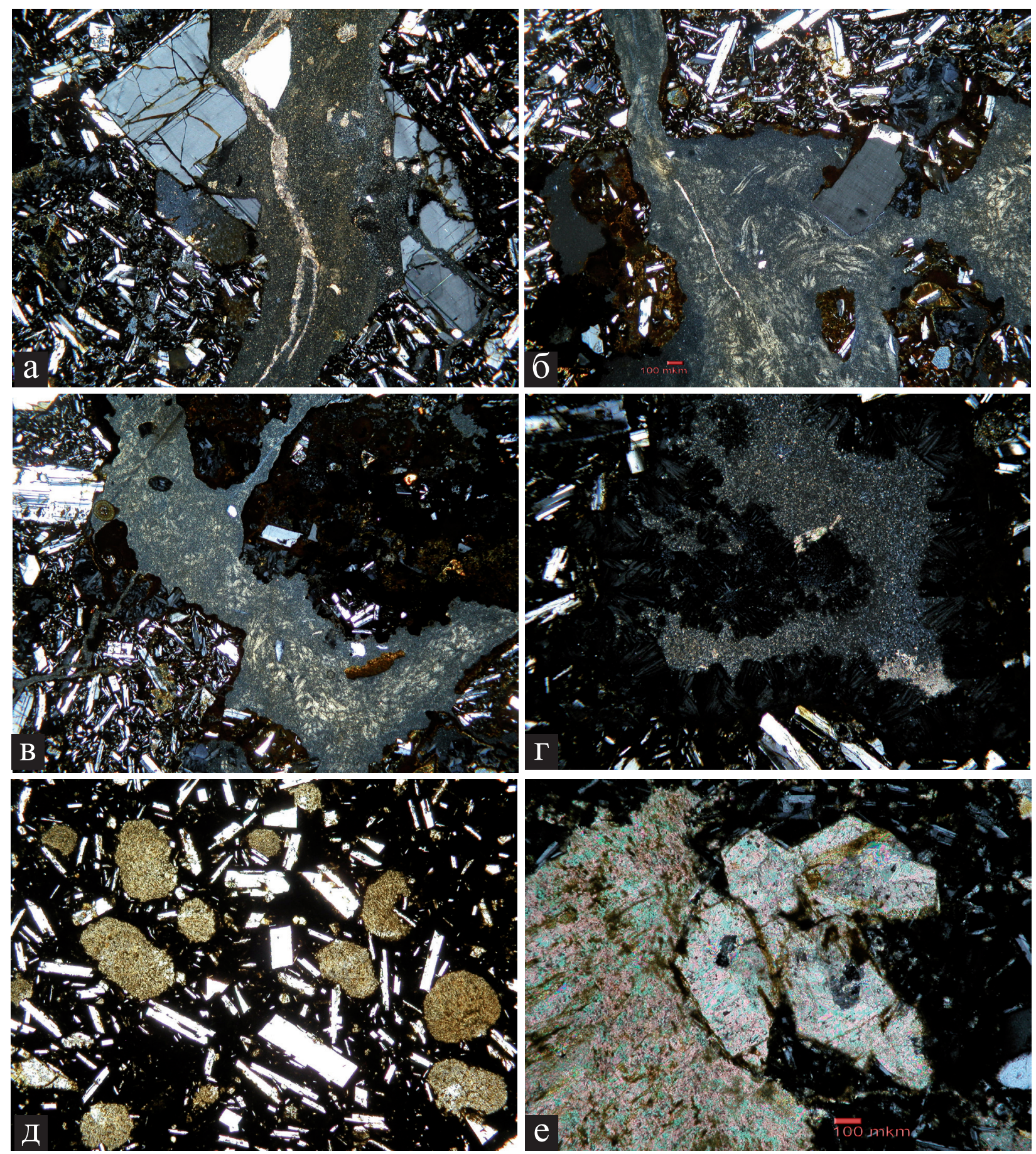

Рис. 3. Фото шлифов вулканитов с включениями карбонатного осадка подвергнутого процессам пирометаморфизма.

a - прожилок карбонатного метаморфизованного осадка разламывает крупный вкрапленник полевого шпата в трахибазальте; б - участок трахибазальта вверху с лейстами плагиоклаза внизу карбонатный осадок, в котором видны процессы пирометаморфизма и на границе формируются буро-коричневые зоны стекла; в - область пироморфизма на границы лавы и осадка. В осадке отмечаются остатки фараминифер отмечается перекристаллизция и образования метаморфогенных минералов. Характерно также бурые стекла; г- образования каймы кресс-комулатов метаморфогенных минералов на границе расплава и осадков. В центре осадка формируется кристалличесекий кальцит (белое включение); д - масса округлых карбонатных включений осадка в мезостазисе лавы; е - аморфного карбонатный осадок и крупные вкрапленники кальцита. 
чем за счет влияние водно-солевых морских растворов температуры плавления будут падать и это обеспечит понижение вязкости расплавов. Что в свою очередь увеличит время существования магматических очагов и время взаимодействия расплавов с окружающей средой. Следовательно, в расплав будут поступать характерные элементы - $\mathrm{Sr}, \mathrm{Ba}$, а в окружающую среду подкисленные растворы, создающие гидрохимические барьеры на границе осадок - лава или лава - морская вода. Такие устойчивые гидротермальные системы могут функционировать достаточно долго для образования гидрохимических аномалий вокруг подводных гор и гайотов.

\section{Выводы}

Подводя итого можно заключить, что на гайотах широко развиты процессы молодого подводного вулканизма, что подтверждается геологическими, геоморфологическими и петрографическими данными. Это несомненно приведет к особой гидрохимической обстановке в районе извержений - увеличению кислотности морской среды, повышению газонасыщенности и процессам химического преобразования базальтовых расплавов в щелочные высоко кальциевые магмы.

\section{Благодарности}

Данная работы выполнена благодаря финансовой поддержки государственного задания Программы Президиума РАН №49 по теме «Внутриплитный вулканизм Тихого океана: оценка масштаба и роли в геодинамике ложа, влияния на состав океанской воды и на гидрогенный рудогенез». Автор также приносит благодарность руководству АО «Южморгеология» за возможность участвовать в рейсе и получить материалы для исследования.

\section{Литература}

1. Chadwick William W., David A. Butterfield, Robert W. Embley, Verena Tunnicliffe, Julie A. Huber, Scott L. Nooner, and David A. Clague Axial Seamount Spot-Light $145^{\circ} 57.00^{\prime} \mathrm{N}, 130^{\circ} 00.00^{\prime} \mathrm{W}$ Oceanography 2010, V. 23. N.1. P. 38-39.

2. Dziak R.P., Baker E.T., Shaw A.M., Bohnenstiehl D.R., Chadwick Jr. W.W., Haxel J.H. and Matsumoto H., S.L. Walker Flux measurements of explosive degassing using a yearlong hydroacoustic record at an erupting submarine volcano Geochemistry, Geophysics, Geosystems. 2012. V. 13. N. 1. P. 1-14.

3. Lopez Blanco C., M. J., R. Abella, B. Brenes, V. M. Cabrera Rodríguez, B. Casas, I. Domínguez Cerdeña, A. Felpeto, M. Fernández de Villalta, C. del Fresno, O. García, M. J. García-Arias, L. García-Cañada, A. et. Al Monitoring the volcanic unrest of El Hierro (Canary Islands) before the onset of the 2011-2012 submarine eruption Geophysical Research Letters 2012. V. 39. L13303, P. 1-7.

4. Mitchell, N. C., Stretch, R., Oppenheimer, C., Kay, D., \& Beier, C. Cone morphologies associated with shallow marine eruptions: east Pico Island, Azores. Bulletin of volcanology 2012. V. 74(10). P. 2289-2301.

5. Santana-Casiano J. M., M. Gonza'lez-Da'vila, E. Fraile-Nuez, D. de Armas, A. G. Gonza'lez, J. F. Domı'nguezYanes \& J. Esca'nez The natural ocean acidification and fertilization event caused by the submarine eruption of El Hierro Scientific Reports www.nature.com / scientificreports 2013. V. 3. P. 1140.8 p. 